January 29, 2013

\title{
National Representation in Supranational Institutions: The Case of the European Central Bank
}

\author{
Harald Badinger \\ Wirtschaftsuniversität Wien
}

\author{
Volker Nitsch \\ Technische Universität Darmstadt
}

\begin{abstract}
$\underline{\text { Abstract }}$
Supranational institutions face an important trade-off when hiring personnel. On the one hand, hiring decisions are based, as in most organizations, on a candidate's professional qualifications. On the other hand, supranational institutions often aim for broad national representation. Reviewing evidence from the European Central Bank, we show that nationality is indeed relevant for both hiring and decision-making. Specifically, we find a disproportionately narrow spread of national representation in the top management of the ECB. Further, there is evidence for the existence of national networks between adjacent management layers. Finally, monetary policy decisions seem to be linked to national representation in the core business areas of the ECB. Examining a sample of 27 European countries over the period from 1999 to 2008, we estimate Taylor rules for alternative sets of euro area aggregates derived from different weighting schemes of national macroeconomic data. Our results indicate that weights based on national representation in the mid-level management of the ECB's core business areas best describe the central bank's interest-rate setting behavior.
\end{abstract}

JEL Code: E02, E58, H83

Keywords: organization; central bank; nationality; monetary policy

* We thank Helge Berger, Petra Gerlach-Kristen, Jan-Egbert Sturm, Peter Tillmann and participants at presentations in Darmstadt, Frankfurt, Osnabrück, Portland, Vienna and Zurich for helpful comments. Michael Kuhn provided able research assistance.

\section{Addresses:}

Badinger: Vienna University of Economics and Business (WU), Department of Economics, Augasse 2-6, A-1090 Vienna, Austria, Tel.: +43-1 31336 - 4133, Fax: +43-1 31336 - 758, Email: harald.badinger@wu.ac.at, Web: http://www.wu.ac.at/ie

Nitsch: Darmstadt University of Technology, Department of Law and Economics, Marktplatz 15, Residenzschloss, D-64283 Darmstadt, Germany, Tel.: +49-6151-16 2436, Fax: +49-6151-16 5652, E-mail: nitsch@vwl.tu-darmstadt.de, Web: http://www.vwl2.wi.tudarmstadt.de 


\section{Introduction}

In central banking, the geographical background of decision-makers and staff is often an issue of considerable relevance. Some central banks require that its staff members have the nationality of the home country. The central bank of the Philippines, for instance, requires that applicants for employment must be Filipino citizens. ${ }^{1}$ Other central banks have established monetary policy decision-making bodies in which, by law, (some) seats are explicitly allocated by region. In Pakistan, for instance, the central bank’s central board of directors comprises one director from each of the provinces. ${ }^{2}$

Having no firm basis in theory, the focus on geographical representation has, in practice, both benefits and costs. Governments and central banks that implement such rules generally aim to improve decision-making and credibility, two important conditions for the success of monetary policy. Specifically, it is argued that regional representatives bring with them specific knowledge of local conditions, thereby allowing to collect and process a broader range of information. Also, regional representatives are able to communicate decisions to a wider public. ${ }^{3}$ At the same time, however, when the geographical background of an individual is taken explicitly into consideration, other potential criteria, most notably a candidate's professional qualifications, automatically become relatively less important for appointment and promotion.

In this paper, we examine empirically issues related to the geographical representation of personnel in central banks. Analyzing the composition of the management team at the European Central Bank (ECB), we ask whether regional features matter for employment. We also search for evidence of networks among staff members along regional lines. Finally, we

\footnotetext{
1 See http://www.bsp.gov.ph/about/recruitment.asp. Citizenship is a requirement that is occasionally even included in the central bank law, typically for influential positions such as board members or shareholders. For instance, for members of the Monetary Committee, Article 16 of the Bank of Israel law stipulates that "[a] member from amongst the public shall be qualified for appointment if he is a resident of Israel" (see http://www.bankisrael.gov.il/deptdata/pikuah/bank_hakika/eng/new_law_2010_eng.pdf). The South African Reserve Bank Act requires, in Article 4, that "[n]o person shall be appointed or elected as or remain a director if he or she is not resident in the Republic" (see

http://www.reservebank.co.za/internet/Publication.nsf/LADV/7DC59462E47AFDDF42256ED60038AE5C/\$Fil e/S+A+Reserve+Bank+Act.pdf). The State Bank of Pakistan Act notes that "no person shall be registered as a shareholder [...] who is not a citizen of Pakistan" (see http://www.sbp.org.pk/about/act/SBP-Act.pdf).

2 See http://www.sbp.org.pk/about/act/SBP-Act.pdf. In similar fashion, the central board of directors of the Reserve Bank of India comprises one director from each of the four local boards (see http://rbidocs.rbi.org.in/rdocs/Publications/PDFs/RBIA1934170510.pdf). Central banks that aim for broad regional representation in their supervisory bodies include Danmarks Nationalbank and the Swiss National Bank.

${ }^{3}$ See, for instance, Goodfriend (1999) for a more detailed discussion.
} 
examine whether the regional composition of central bank staff has a measurable impact on policy-making.

The focus on the ECB has, for our purposes, a number of useful features. First, the ECB is a multinational institution, such that nationality is a reasonable approach to differentiate geographical background. ${ }^{4}$ Also, nationality is a personal characteristic that is easily observed, both internally and externally. Second, the ECB is a young institution. Having been officially established in 1998, it had to build up its staff quickly from virtually zero so that there are hardly persistence effects in recruiting. Third, the ECB is an institution of great policy relevance. The ECB is not only the largest European Union financial body, it also has financial and organizational autonomy. ${ }^{5}$ Given the ECB's genuine powers, governments of euro area member states should have a strong incentive for national representation in this institution. ${ }^{6}$ Fourth, in contrast to other policy areas in the European Union, monetary policy directly affects economic conditions in all euro area member countries, thereby providing another strong incentive for national representation.

In our analysis, we focus particularly on national representation at the management level of the ECB, a choice that is motivated by a large organizational literature. For instance, Pfeffer (1985, p. 68) argues that "[o]rganizations are full of people. It often seems only natural and appropriate to analyze and manage organizations using individuals as the units of analysis." Thereby, we go substantially beyond previous work with a focus on national representation in the ECB's decision-making body, the Governing Council. ${ }^{7}$ Instead of examining de jure representation of countries as defined in political documents, we analyze de facto presence of nationals in the institution. Specifically, we estimate panel data models for staff shares of the 27 member states of the European Union (EU) in the top management of the ECB over the period from 1999 through 2010.

Previewing our results, we find that a nation's share of ECB managers is reasonably explained by country-level determinants of job applications (such as a country's distance from the ECB

\footnotetext{
${ }^{4}$ Egeberg (1996) follows a similar approach.

${ }^{5}$ The European Investment Bank and the European Investment Fund are other financial bodies of the European Union (see http://europa.eu/institutions/financial/index_en.htm).

${ }^{6}$ Scheller (2004, p. 44) notes: "As an organization created by the EC Treaty, the ECB enjoys genuine powers. [...] This feature distinguishes the ECB from the various decentralized agencies of the Community, which possess their own legal personality but have competences delegated to them by the Community institutions."

${ }^{7}$ Examples include, among others, Heinemann and Huefner (2004) and Belke and von Schnurbein (2012).
} 
headquarter) rather than broad geographical representation. This finding seems to indicate that hiring decisions are generally made on the basis of a candidate's professional qualifications. Still, national background also seems to matter for recruitment. There is evidence that strong national representation at a particular management level is typically associated with similarly strong national presence at the subordinate management layer. Finally, based on Taylor rule estimates to describe the ECB's interest-rate setting behavior, we find that monetary policy decisions are most closely linked to national representation in the core business areas of the ECB.

The remainder of the paper is organized as follows. Section II reviews the relevant literature. Section III provides some institutional background on the European Central Bank, followed by a description of the data in section IV. The heart of the paper is section V which presents our empirical model and the estimation results. Section VI briefly summarizes our findings.

\section{Related Literature}

Our paper is related to various strands of the literature. There has been extensive work, for instance, on regional representation in a central bank's main decision-making body, the monetary policy committee. Specifically, a number of studies have examined to what extent the presence of regional representatives in the board has affected monetary policy decisions. Reviewing the voting records of individual board members, there seems to be consistent evidence that regional economic conditions help explain dissent voting of regional representatives. Berger and De Haan (2002), for example, argue that economic differences across German states translated into differences in voting behavior in the Bundesbank's Governing Council (Zentralbankrat) in which all German state central banks held voting rights. Similarly, Gildea (1992), Meade and Sheets (2005), and Chappell Jr., McGregor and Vermilyea (2008), among others, find that members of the Federal Open Market Committee in the US are influenced in voting by economic conditions in the regions that they represent. None of these papers has considered regional representation at the staff level.

A sizable body of work is concerned with the design of central bank committees more generally. With reference to regional representation, Berger, Nitsch, and Lybek (2008) find that politically fragmented countries typically have larger monetary policy committees. Berger and Nitsch (2011) show that central banks with required regional representation tend to achieve, on average, lower inflation. 
Another relevant strand of the literature focuses on the effects of individuals in organizations. In an interesting study, Bertrand and Schoar (2003) find that corporate managers measurably affect firm behavior and economic performance. Moreover, they identify differences in "styles" across managers which can then be linked to observable managerial characteristics. For instance, Bertrand and Schoar (2003) note that executives from earlier birth cohorts seem to be on average more conservative, while managers with an MBA degree tend to follow more aggressive strategies. For central banks, Göhlmann and Vaubel (2007) find that board members who were previously member of the central bank staff prefer significantly lower inflation rates than former politicians do. In similar fashion, Dreher, Lamla, Lein, and Somogyi (2009) argue that heads of government who are former entrepreneurs are more likely to implement market-liberalizing reforms; Besley, Montalvo and Reynal-Querol (2011) find that more educated political leaders generate higher economic growth. While we are generally sympathetic with the finding that individuals have an effect on organizational outcomes, we deviate from this literature in various respects. For one thing, our focus is exclusively on the regional background of individuals instead of their educational and professional qualifications. ${ }^{8}$ More importantly, we examine a much broader group of individuals. Instead of examining the role of leaders, we cover in our analysis the (various) top management levels of an organization.

In this respect, our approach is also related to an interesting literature, mainly in management science, on the demographic structure of organizations. This literature refrains from the analysis of individual features and emphasizes, in contrast, the compositional aspects of organizations. Pfeffer (1985, p. 79) argues, for instance, that "[t]he difficulty with this [individualistic] approach is its neglect of the interdependence and relationships that are the essential, indeed defining, characteristic of organizations."

\section{The ECB}

The process of European integration is characterized by a delegation of functions, in a growing number of policy areas, from the national level to the European Union. In many instances this has led to the establishment of new multi- and supranational institutions. ${ }^{9}$ The

\footnotetext{
${ }^{8}$ While it would be interesting to also analyze personal characteristics of managers other than nationality, relevant data for such a large and diverse group of people is almost impossible to obtain.

${ }^{9}$ As a result, there are, in the meantime, many EU institutions, agencies, bodies, commissions and committees. An early example is the EURATOM Supply Agency, founded in 1960 and headquartered in Luxembourg, which
} 
European Central Bank is a particularly important case in point. When the decision was taken to complete the Single Market with a single currency, responsibilities for monetary policy needed to be centralized. As a result, the ECB was created, which forms, along with the national central banks of the euro area member countries, the monetary policy-making authority in the euro area, the Eurosystem. ${ }^{10}$

The official agreements about the establishment of the ECB date back to the Treaty on European Union ('Maastricht Treaty'), which was signed in Maastricht on 7 February 1992. The Treaty defined the monetary policy framework in the economic and monetary union; it also contained the Statute of the European System of Central Banks (ESCB) and of the ECB which was attached as a Protocol to the Treaty. ${ }^{11}$

For the immediate preparatory work, the European Monetary Institute (EMI) was established as a transitory body on 1 January $1994 .^{12}$ The objective of the EMI was, among other things, to specify the regulatory, organizational and logistical framework necessary for the ESCB to perform its tasks. Based on the EMI's conceptual design, the ECB was finally established on 1 June 1998, while the EMI went into liquidation. Seven months later, on 1 January 1999, eleven EU member states adopted the euro as their common currency, and the ECB took over responsibility for conducting the single monetary policy in the euro area.

As liquidator of the EMI, the ECB inherited the EMI infrastructure. Scheller (2004, p. 25) argues that the infrastructure included "a body of staff which had been prepared to undertake its duties at the ECB". Most of the EMI staff, however, were on fixed-term contracts, so that the ECB faced effectively no restrictions from the past in setting up management and staffing

is responsible for the regular and equitable supply of nuclear fuels for Community users. A very recent example, in contrast, is the European Banking Authority, established on 1 January 2011 and headquartered in London, which is a regulatory agency for the financial sector. See http://europa.eu/institutions/inst/index_en.htm for an overview.

${ }^{10}$ Baldwin and Wyplosz (2009, p. 495) note: "Each member [country] still comes equipped with its own central bank, the last remaining vestige of lost monetary sovereignty. No matter how daring the founding fathers of the EMU were, they stopped short of merging the national central banks into a single institution, partly for fear of having to dismiss thousands of employees."

${ }^{11}$ Article 105(2) of the Treaty notes: "The basic tasks to be carried out through the ESCB shall be: to define and implement the monetary policy of the Community[...]." Article 106 notes: "(1) The ESCB shall be composed of the ECB and of the national central banks. (2) The ECB shall have legal personality." See http://www.ecb.int/ecb/legal/pdf/maastricht_en.pdf.

12 The EMI replaced the Committee of Governors of the central banks of the member states, as specified in Article 109f(1) of the Treaty. Operationally, the EMI started with the 28 staff members of the secretariat of the Committee of Governors in Basle. 
structures. ${ }^{13}$ More importantly, staff size of the ECB has quadrupled after establishment, rising from a permanent staff of 407 on 31 May 1998 to a full-time equivalent number of 1607 at the end of 2010. Over the same period, the number of managerial positions has increased by more than factor three, rising from 45 to 156. In sum, the ECB can be plausibly described as an institution, which had to build up its staff from virtually zero after creation.

For the employment decisions of the ECB, there are no political, administrative or other external constraints. Partly reflecting the institution's independence, Article 36.1 of the Statute of the ESCB and the ECB stipulates that "[t]he Governing Council [of the ECB], on a proposal from the Executive Board, shall lay down the conditions of employment of the staff of the ECB". The conditions were then fixed in the Rules of Procedure at the ECB, adopted by the Governing Council, and turn out to be very general principles. Article 20.2 of the Rules states that "[m]embers of staff shall be selected, appointed and promoted with due regard to the principles of professional qualification, publicity, transparency, equal access and nondiscrimination." 14

The selection process was further specified in Administrative Circular 5/2004 which contains detailed rules for recruitment. Apart from the general rule that the ECB appoints only nationals of European Union member states, which seems to be in line with the Staff Regulations of officials of the European Communities ${ }^{15}$, this document lays down additional rules on nationality. Specifically, recruitment at the ECB is directed at the broadest possible geographical representation, without imposing a specific national quota. Article 5.4 of the Circular explicitly states: "In the event that candidates have equal qualifications for a position, gender and/or nationality may be used as additional criteria for the selection decision with a view to achieving a balanced representation of gender and/or nationalities." ${ }^{16}$ In the following, we examine national representation at the ECB at various levels of hierarchy in more detail.

\footnotetext{
${ }^{13}$ The Annual Report of the EMI for 1994 states (p. 66): "Members of staff have generally been appointed on three-year fixed-term contracts."; see http://www.ecb.int/pub/pdf/annrep/ar1994en.pdf. The view of no contractual restrictions is confirmed in the Annual Report of the ECB for 1998, noting (p. 145): "Most EMI staff contracts were due to expire at the end of 1998. By the date on which these statements were drawn up, 322 permanent staff had transferred to the ECB under new contracts."; see http://www.ecb.int/pub/pdf/annrep/ar1998en.pdf.

${ }^{14}$ See http:// www.ecb.int/ecb/legal/pdf/__33819981215en00280033.pdf.

${ }^{15}$ See http://eur-lex.europa.eu/LexUriServ/site/en/consleg/1962/R/01962R0031-20060701-en.pdf.

${ }^{16}$ Article 5.2 notes: "Without prejudice to the principle stated above, the selection process shall also be directed to securing the broadest possible geographical basis from among nationals of Member States of the European Union. No nationality quota shall apply and no vacancy shall be reserved for a specific nationality." See http://www.ecb.int/ecb/jobs/pdf/recruitmentrules.pdf.
} 


\section{Data}

At the heart of our paper is a newly compiled panel data set on the nationality of top managers at the European Central Bank. In contrast to previous studies which often focus on a central bank's monetary policy committee, we cover all management layers of the ECB, including the heads of directorates, divisions and sections. Our data set is based on the organizational charts of the ECB. The ECB regularly publishes charts of its organizational structure along with the names (but not the nationalities) of the responsible managers, in the most current version, on its website. We have compiled the charts for the period from 1999 to 2010; the data is on an annual basis and refers to the organizational structure at the beginning of each year. ${ }^{17}$

In total, the ECB has appointed, since its establishment, 210 individuals on managerial positions (including deputies). For each individual, we aim to identify the nationality. To do so, we use a variety of sources, including internet search, newswire reports and personal communication. Overall, we were able to confirm the nationality of 190 individuals, except for a few managers of mainly technical and administrative divisions. In our analysis, we deal with those missings in three ways. As our baseline approach, we impose nationality based on the name of the individual. This procedure is relatively straightforward and simple; it also allows us to analyze the full sample. Alternatively, we drop individuals without proper information on nationality. Finally, we focus our analysis on the divisions of key importance for the operations of the ECB (core business areas), thereby reducing the number of individuals with missing nationality.

The top decision-making body of the ECB is the Governing Council, which comprises the Presidents/Governors of the national central banks of the member countries of the euro area and the 6-member Executive Board. Given the politically-determined composition of this body (with members being appointed at the level of heads of state or government), our focus is on the remaining levels of management. The ECB's organizational structure below the Governing Council initially consisted of two management levels; i) the directorates general or directorates, and ii) divisions. After a period of strong growth of the institution, sections were introduced as third management level in 2003. Table 1 describes the evolution of the number of (filled) management positions at the ECB over time. In addition, there is, for each position, the option of establishing a deputy head. In our empirical analysis, we experiment with both

\footnotetext{
${ }^{17}$ We are indebted to the ECB's Press Division for the kind provision of missing information.
} 
groups of managers, heads only and heads and deputies combined. Fortunately, our results turn out to be generally consistent across samples.

$<$ Table 1 here $>$

Our central bank data is augmented with data from a number of standard sources, including the IMF's International Financial Statistics, the World Bank's World Development Indicators and OECD statistics. A detailed list of variables and sources is provided in an appendix. Our sample covers the 27 member countries of the European Union. Since 12 of these countries have entered the European Union during the sample period, the panel is unbalanced. We only include countries which, as members of the EU, have subscribed to the capital of the ECB. ${ }^{18}$

\section{$\underline{\text { V. Empirical Analysis }}$}

\subsection{Who Gets Appointed?}

We begin our empirical analysis by examining patterns of national representation in the management of the ECB. Specifically, we aim to identify to what extent the ECB's aim of "broadest possible geographical representation" indeed matters for recruitment. Our empirical approach is straight forward. To quantify potential country biases in the ECB's hiring policy, we examine the extent to which the national distribution of management positions is described by the following two (benchmark) principles:

i) Equal representation $(E)$, or representation with parity, which implies that each member state holds the same percentage of the ECB's top management staff such that $S_{i, t}^{E}=$ $S_{t}^{E}=1 / N_{t}$, where $i$ is the country index and $N_{t}$ is the number of EU member states in year $t .^{19}$

\footnotetext{
${ }^{18}$ In practice, the ECB has started recruiting from accession countries more than a year before entry into the European Union (that is, immediately after the treaty of accession to the EU was signed). For our analysis, however, this difference is without relevance.

19 Since citizens of all EU member states are eligible for employment with the ECB (see http://www.ecb.int/ecb/jobs/apply/html/index.en.html), we use the number of EU countries rather than the number of euro area countries, but we control for euro area membership later on.
} 
ii) Proportional representation $(P)$, which implies that the staff share of each member state corresponds to the country's share in the ECB's capital (and, thus, reflects its relative demographic and economic size), which we refer to as $S_{i, t}^{P}{ }^{20}$

If candidates are mainly selected according to their professional qualifications, we would expect that the share of top positions filled by nationals of a member state is largely determined by the available supply of qualified candidates. More explicitly, the probability of a perfect fit of an applicant's personal profile with the requirements of an open position is higher for nationalities with a large pool of applicants. As a result, since the ECB is likely to receive a larger number of applications from individuals of more populous countries, these countries should be disproportionately strongly represented in the ECB. By assumption, our default distribution of candidates is given by the capital subscription key of the ECB. In fact, to the extent that the qualification profiles of applicants are equally distributed across EU member states (a strong assumption that will be relaxed below), national staff shares in the ECB should fit perfectly with the national capital share.

Broad representation of nationalities, in contrast, would imply that the selection decision for hiring or promotion is largely based on an individual's national background. Consequently, qualifications become less relevant for appointment, biasing the distribution towards countries with few(er) representatives. In the extreme, each country has the same share of representatives in the management of the ECB.

We start our investigation by using a highly parsimonious model specification which includes only our two benchmark distributions; that is, we estimate regressions of the form:

$$
R_{i, t}^{\ell}=\eta_{E} S_{t}^{E}+\eta_{P} S_{i, t}^{P}+\varepsilon_{i, t}
$$

where $R_{i, t}^{\ell}$ is country i's share of representatives at management level $\ell$ in year $t, S_{i, t}^{E}$ and $S_{i, t}^{P}$ are the equal and proportional representation staff shares (as defined above), and $\varepsilon_{i, t}$ is a country-specific error term. The main advantage of this reduced-form regression specification is that it allows to identify directly the weight of the two principles of national representation

\footnotetext{
${ }^{20}$ Capital shares are determined (and regularly recalculated) based on a country's total population and GDP (in equal weightings). The shares currently range from 18.94\% for Germany (Deutsche Bundesbank) to 0.06\% for Malta (Central Bank of Malta); see http://www.ecb.int/ecb/orga/capital/html/index.en.html.
} 
in the management of the ECB. As $S_{t}^{E}$ and $S_{i, t}^{P}$ sum to one over all countries $i$, the estimates of $\eta_{E}$ and $\eta_{P}$ are, by least squares algebra, also required to sum to one. ${ }^{21,22}$

In our empirical implementation, we estimate equation (1) separately for individual management levels $\ell$, using an (unbalanced) panel of $27 \mathrm{EU}$ member states over the period from 1999 to 2010 (with a total of 248 observations $^{23}$ ). Moreover, to ensure the robustness of our results, we analyze national staff shares at various levels of aggregation. For instance, in addition to individual management layers, we consider the overall share of countries in the management of the ECB as well as a weighted average of managers across all management levels. ${ }^{24}$ In another exercise, we restrict our analysis to the share of representatives in the ECB's (self-defined) core business areas. These functional units are of particular interest and relevance as they are directly involved in the formulation and implementation of the ECB's monetary policy. ${ }^{25}$

$<$ Table 2 here $>$

Table 2 presents the results. The table contains three panels. The upper panel reports estimates for our baseline measure of national representation in the management of the ECB (based on the nationality of the heads of all the respective units); the remaining two panels tabulate analogous results for alternative representation measures. Across columns, the regressand varies along another dimension, the management level. Specifically, we start our investigation by examining country shares for heads of directorates, divisions and sections (columns 1-3),

\footnotetext{
${ }^{21}$ Note that $N_{t} \bar{R}_{i, t}^{\ell}=N_{t} \bar{S}_{i, t}^{P}=1$, where the bar denotes cross-section averages, while $S_{t}^{E}$ is a time-specific (rescaled) constant. Since $S_{t}^{E}=1 / N_{t}$, it holds for all $t$ (and, therefore, also for the pooled model) that $\hat{\eta}_{E}=$ $N_{t}\left(\bar{R}_{i, t}^{\ell}-\hat{\eta}_{P} \bar{S}_{i, t}^{P}\right)=1-\hat{\eta}_{P}$.

${ }^{22}$ An alternative approach to examine the role of nationality in employment is to test for the (joint) significance of country dummies, holding constant for variables which can reasonably be expected to affect representation without disrespecting the treaties (such as economic size or education). The main drawback of this approach is that the country dummies also capture the effects of time-invariant labor market characteristics (such as, for instance, a country's distance to Frankfurt).

${ }^{23}$ For sections, which were introduced in 2004, sample size reduces to 173 observations.

${ }^{24}$ We assign a weight of 1 for directorates, 0.5 for divisions and 0.25 for sections. Since sections were first introduced in 2004, weighted aggregates for the period before are calculated based on directorates and divisions only to avoid losing observations.

${ }^{25}$ The ECB has defined as its core business areas: Banknotes; Economics; Financial Stability; International and European Relations; Legal Services; Market Operations; Payments and Market Infrastructure; Research; Statistics; the Target2-Securities Program; and the ECB Permanent Representation in Washington, DC. Supporting business areas are: Counsel to the Executive Board; Administration; Communications; Human Resources, Budget and Organization; Information Systems; Internal Audit and Secretariat and Language Services. See http://www.ecb.int/ecb/educational/facts/orga/html/or_005.en.html.
} 
followed by an exploration of aggregate measures as described (columns 4-5). In total, the table reports (paired) coefficient estimates of $\eta_{E}$ and $\eta_{P}$ for 15 different measures of country representation in the ECB.

Reviewing the results, two observations are particularly noteworthy. First, the estimated coefficients on the capital share sizably and consistently exceed the corresponding estimates on the parity benchmark. While the point estimates of $\eta_{P}$ are always statistically highly significant and take values close to one, the $\eta_{E}$ estimates are typically much smaller in magnitude and often statistically indifferent from zero at conventional levels of significance. These findings indicate that the geographical patterns of top-level staff employment at the ECB rarely deviate from proportional representation; the majority of positions are filled with nationals from countries with the largest contributions to the ECB's capital. Provided that our (working) assumption is correct that the supply of (qualified) applicants is roughly in proportion to the size of a country, professional qualifications clearly seem to dominate the national background in hiring.

Second, the estimates of $\eta_{E}$ turn out to be positive, economically relevant and statistically significant (with a t-statistic of around 3) for the highest level of management and responsibility in the organizational structure of the ECB, the heads of directorates and directorates general. The weight assigned to $S^{E}$, the equal representation share of countries, is about 0.2 for these top positions; the top (directorate) level also appears to measurably affect the results for our aggregate measures of national representation. A plausible explanation for this finding is that the director position is highly competitive, allowing to recruit qualified candidates from a broad range of countries. ${ }^{26}$

Our reduced-form regressions implicitly assume that a constant fraction of a country's population is seeking employment at the ECB; a national staff share close to the country's capital share is interpreted as evidence of proportional representation. In practice, however, the supply of qualified candidates is unlikely to be uniformly distributed across EU member states. For instance, employment at the ECB may be particularly attractive for individuals from economically well-educated and geographically close countries. Therefore, to deal with

\footnotetext{
${ }^{26}$ For the Governing Council and the Executive Board, the point estimates of $\eta_{P}$ are 0.71 and 0.30 , respectively. As argued above, however, the estimation results for these politically-determined executive management layers should be interpreted with caution.
} 
this issue, we augment equation (1) by adding a host of other factors that might affect a country's supply of labor (suitably trained for employment at the ECB):

$$
R_{i, t}^{\ell}=\eta_{E} S_{t}^{E}+\eta_{P} S_{i, t}^{P}+\mathbf{x}_{i, t} \boldsymbol{\beta}+\varepsilon_{i, t}
$$

In particular, we employ the following set of (time-variant) country-specific control variables $\left(\mathbf{x}_{i, t}\right)$ : a binary dummy variable which takes the value of one if country $i$ is a member of the euro area at time $t$ (and zero otherwise); the length of $i$ 's membership in the euro area in years; the log of distance between the national capital of $i$ and Frankfurt (Germany), the location of the headquarter of the ECB; a dummy variable which takes the value of one if $i$ has a common land border with Germany (and zero otherwise); the share of the population with upper and tertiary education; the number of staff of the national central bank relative to population size; and the share of the population speaking the German language. Moreover, in order to ensure comparability with the results from our baseline specification, we impose the restriction that $\eta_{E}=\left(1-\eta_{P}\right)$, without loss of generality. ${ }^{27}$

Table 3 presents the results. As before, the columns tabulate coefficient estimates for individual management levels and aggregate representation shares. In addition, we provide, for completeness, results for national representation in the Governing Council of the ECB.

The key parameter of interest to us is (again) $\eta_{E}$, the estimated parameter on the benchmark share of equal representation. As shown, the point estimates of $\eta_{E}$ generally increase in both magnitude and significance, after controlling for a broad(er) range of factors potentially affecting the national number of applicants. Although the weight assigned to $S^{E}$ is still relatively moderate, there is clear evidence that the ECB's appointment decisions tend to bias the national staff shares towards a "broad geographical representation", once we take (properly) into account that the pool of candidates for employment at the ECB varies across countries. Further, it is interesting to note that this pattern holds particularly for the upper layers of management, confirming our earlier findings. ${ }^{28}$

$<$ Table 3 here $>$

\footnotetext{
${ }^{27}$ Under the null hypothesis that $\eta_{E}=0$, the restriction implies a simple rescaling of $\eta_{P}$ to which least squares estimation is invariant.

${ }^{28}$ Without taking the precise results too literally, it seems reassuring that the largest estimates of $\eta_{E}$ are obtained for the composition of the Governing Council and the Executive Board.
} 
While the control variables are not of direct interest, the results turn out to be reasonable and significant. For instance, the availability of qualified personnel seems to matter for representation beyond a country's capital share: Countries with a larger (relative) staff size of the national central bank generally have more representatives in the management of the ECB. Also, it seems easier to find and attract promising candidates for the filling of positions if they are already close to Frankfurt. In contrast, only for top management positions at the ECB, membership in the euro area is significantly (positively) associated with national representation, possibly reflecting the ECB's aspiration to document its EU-wide recruitment strategy in the organizational chart; this approach seems to be most easily possible and justifiable for less influential management positions. There are similarly mixed results for other country features, such as familiarity with the German language. Overall, the regressions fit the data well; more than three-fourths of the variation in national representation is explained by our model.

\section{$<$ Table 4 here $>$}

As before, we have performed extensive robustness checks. To economize on space, Table 4 presents a subset of the results of those exercises, tabulating estimates for the specification with the total number of representatives only. We modify our sample along various dimensions. In the first column, we examine a sample when individuals for which we have no confirmed information on nationality are dropped. Our baseline results remain basically unchanged for this perturbation. Next, we examine pooled information on the department heads and their deputies, again producing essentially similar results. In another exercise, we restrict our analysis on managers in the ECB's core business areas. Interestingly, for the core areas, membership in the euro area seems to become an important precondition for appointment. In contrast, knowledge of the German language becomes less relevant than for the sample of all organizational units. A plausible explanation may be that it is especially in supporting business areas (such as infrastructure), where interactions with local businesses (and, thus, the ability to properly communicate with locals) are particularly important. Again, none of our results are changed when we additionally take ECB managers with deputy function into consideration. Finally, our baseline results are basically confirmed when Germany is dropped from the sample, though the results for the German language and neighboring countries appear to be somewhat driven by German nationals in the ECB. 


\subsection{Does Presence in Top Management Matter for Appointment?}

In a next step, we explore the possible existence of national networks in the ECB. Specifically, we analyze whether national presence at top management levels also affects national representation at lower management levels. It could be argued, for instance, that, after a change in the ECB's top management, nationals of other countries are targeted for lower-level positions in order to achieve broad geographical representation within a given business area; that is, there should be a gradual replacement at lower management levels (to the extent individual contracts allow for such behavior ${ }^{29}$ ). Alternatively, nationals at the top level may act as a door-opener for fellow nationals. Specifically, given that in the day-to-day business, personal interaction is often crucially important, there may be a tendency to select subordinates that share the same language and culture.

To analyze these issues empirically, we (further) augment our baseline regression framework by measures of national presence in higher management levels. That is, we estimate variants of the following augmented version of equation (2):

$$
R_{i, t}^{\ell}=\kappa_{P} P_{i, t}+\kappa_{V P} V P_{i, t}+\kappa_{E B} E B_{i, t}+\kappa_{\ell^{\prime}} R_{i, t}^{\ell^{\prime}}+\eta_{E} S_{t}^{E}+\eta_{P} S_{i, t}^{P}+\mathbf{x}_{i, t} \boldsymbol{\beta}+\varepsilon_{i, t} .
$$

where $P$ is a binary dummy variable that takes the value of one if the President of the ECB is from country $i$ (and zero otherwise), $V P$ and $E B$ are analogous variables for the Vice President of the ECB and other Executive Board members, respectively, and $R_{i, t}^{\ell^{\prime}}$ is the share of national representation at management level $\ell^{\prime}$ superior to the management level of the regressand $\ell$. (For sections, these are the directorates and divisions; for divisions, these are directorates only.) Overall, we consider this a very demanding specification since we already control for patterns of country representation at the management level.

Estimation results for equation (3) are presented in Table 5. While all regressions include our benchmark distribution shares and the full set of controls $\mathbf{x}$, only the estimates of the $\kappa$ 's are tabulated for the sake of brevity. In addition, we note that none of our previous estimates of $\eta_{E}$ and $\eta_{P}$ is sizably affected by adding information on superior management levels.

\footnotetext{
${ }^{29}$ Changes in the responsibilities of senior managers in the ECB are indeed "in accordance with its policy to promote mobility within the ECB, which is aimed at strengthening the efficiency and effectiveness of the organization"; see http://www.ecb.int/press/pr/date/2006/html/pr060803_2.en.html.
} 
As before, we proceed sequentially, beginning with the most senior management level (directorates) on the left of the table. The results in the first column indicate that individuals who share the nationality of the president are indeed more likely to be appointed as head of directorate/directorate general, holding constant other country-specific determinants for representation in the top management of the ECB. As noted before, however, this observation may be not particularly surprising, given that there are some sensitive positions (such as head of communications) where cultural differences between individuals should be avoided. There is no measurable effect, in contrast, for other members of the Executive Board, including the Vice President.

$<$ Table 5 here $>$

The next column presents analogous results for the second management level, heads of divisions. The results are virtually identical, except for the effect of Vice Presidency. The (negative) coefficient implies that fellow nationals face a disproportionately low probability of appointment at this level. When we extend our analysis to also include the share of representatives at the level of directorates (column 3), the coefficient on this variable takes a positive value but is statistically indistinguishable from zero.

There is more weak evidence on national network effects between adjacent management layers at the lowest ECB management level, sections. The results for alternative regression specifications are tabulated in the last four columns on the right of Table 5. While the estimation results for the various levels of senior management are mixed, with a slight overrepresentation of the home country of the President among section heads and a disproportionately low presence of the nationality of the Vice President and other Executive Board members, the national presence at the division level (i.e., the direct supervisor) has a measurable positive effect on representation at the section level. Overall, our findings suggest that there is a positive association between national representation shares at adjacent management levels, indicating the existence of national network effects.

\section{$\underline{5.3 \text { Monetary Policy Effects of National Representation }}$}

\subsubsection{Empirical Strategy}


Finally, we ask: Does national representation in the ECB affect monetary policy decisionmaking? Previous studies have strongly focused on the national distribution of votes in the ECB decision-making body, the Governing Council. ${ }^{30}$ We examine the association between national representation in the ECB's top management and monetary policy decision-making.

To analyze this issue, we estimate Taylor-type interest rate rules which specify the nominal interest rate as a function of inflation and the output gap; Taylor rules are typically found to describe actual monetary policy reasonably well. For the ECB, whose monetary policy is targeted at the euro area, the variables of interest for policy-making are country-size weighted averages of national data from euro area member countries. Consequently, we would expect that a Taylor rule specification for euro area aggregates of inflation and output based on the economic weight of member countries best describes the ECB's monetary policy behavior. Possible effects of national representation on policy-making are then identified by investigating the empirical fit of Taylor rules based on alternative weighting schemes for national data, using a country's staff share in the ECB rather than its economic weight to compute euro area aggregates. Since a comparison of the fit of different models does not allow rigorous statistical inference with respect to superiority of one model, we consider the results mainly as indicative. ${ }^{31}$

\subsubsection{Model Specification and Data}

Our baseline specification follows English, Nelson and Sack (2003), who use a Taylor rule specification that allows for both partial adjustment of the actual to the target interest rate and for serial correlation in the error term. These two features are considered as relevant in explaining deviations of the actual interest rate from the rate implied by a standard (static) Taylor rule. $^{32}$

\footnotetext{
${ }^{30}$ For instance, Berger and Mueller (2007) argue that the pattern of over- and under-representation of member countries in the ECB Council might be extreme. Hayo and Méon (2011) examine empirically the effect of the national composition of the Governing Council on decision-making.

${ }^{31}$ There are also other reasons for a cautious interpretation of the results. Taylor rules focus on only one aspect of monetary policy, the key interest rate, thereby ignoring other policy measures taken by central banks; these measures (such as the outright monetary transactions program of the ECB) have recently gained in importance for policy-making. Another potential concern is that Taylor rules, while providing an empirically reasonable (ex post) description of monetary policy, often do not turn out as optimal prescriptive rule for monetary policy in theoretical models.

${ }^{32}$ For recent applications of this approach, see Gorter, Jacobs and de Haan (2008) and Sturm and de Haan (2011).
} 
The full model is made up of three equations. Consider a forward-looking Taylor rule in which the target interest rate $i_{t}^{*}$ is described as a function of the deviation of future expected inflation $\pi_{t}^{e}$ from its target $\bar{\pi}_{t}$ and the change in the output gap, i.e., the deviation of expected output growth $\Delta \ln y_{t}^{e}$ from (expected) growth of potential output $\Delta \ln \bar{y}_{t}::^{33}$

$$
i_{t}^{*}=\alpha+\beta\left(\pi_{t}^{e}-\bar{\pi}_{t}\right)+\gamma\left(\Delta \ln y_{t}^{e}-\Delta \ln \bar{y}_{t}\right)
$$

so that $\alpha$ denotes the neutral nominal interest rate, i.e., the interest rate, when inflation is at its target and output growth is equal to trend growth.

In practice, it seems reasonable to assume that the actual interest rate $i$ is adjusted only gradually to its target level so that:

$$
i_{t}=\rho i_{t-1}+(1-\rho) i_{t}^{*}+\vartheta_{t}
$$

where $(1-\rho)$ is the speed of adjustment parameter. Finally, the error term is allowed to exhibit first order serial correlation:

$$
\vartheta_{t}=\delta \vartheta_{t-1}+\varepsilon_{t}
$$

Using then a Cochrane-Orcutt transformation and rewriting the equation in first differences, we obtain (see English, Nelson, and Sack, 2003):

$$
\Delta i_{t}=\rho \Delta i_{t}^{*}+\rho(1-\delta)\left(i_{t-1}^{*}-i_{t-1}\right)+\rho \delta \Delta i_{t-1}+\varepsilon_{t}
$$

which is our benchmark empirical model.

In our empirical implementation, we use the ECB's main refinancing rate as dependent variable. The main refinancing rate is the key interest rate, set by the Governing Council, and assumed to reflect directly the ECB's monetary policy setting behavior. In extensive robustness checks, we also experiment with market-based interest rates, such as the 3-month Euribor and Eonia.

\footnotetext{
${ }^{33}$ In the empirical literature, it has become standard practice to use the change in the output gap rather than its level. Walsh (2003) advocates the use of such a modified Taylor rule in the presence of uncertainty about the output gap. For a discussion of the advantages of using growth rates rather than levels, see Sturm and Wollmershäuser (2008, p. 4).
} 
We estimate our model using monthly data for the period from January 1999 to June $2008 .{ }^{34}$ Data on expected inflation and output growth are obtained from Consensus Economics. Following the literature, we use the professional forecasts of inflation and output growth in the current and the following year to construct monthly measures of real-time expectations for the key macroeconomic variables. ${ }^{35}$ The series for the euro area are then obtained as weighted averages of the country values, i.e.,

$$
\pi_{t, m}^{e}=\sum_{i=1}^{N_{t}} \omega_{i, t} \pi_{i, t, m}^{e} \text { and } y_{t, m}^{e}=\sum_{i=1}^{N_{t}} \omega_{i, t} \Delta y_{i, t, m}^{e}
$$

where, in our benchmark specification, the weight $\omega_{i, t}$ is country i's share in the real GDP of the euro area in year $t$ and $N_{t}$ is the (time-variant) number of euro area member countries. ${ }^{36}$ Finally, in order to quantify macroeconomic conditions as deviation from medium-term targets, we set target inflation to $2 \%$, based on the ECB's definition of price stability, and assume potential output growth of $2.25 \%$, using the mid-point of the interval given by the ECB.

\subsubsection{Estimation Results}

Table 6 presents estimation results for various specifications of the Taylor rule. We proceed stepwise. In the first three columns of the table, we tabulate results when a country's real GDP is used as weight $\omega_{i, t}$ to aggregate national data. ${ }^{37}$ Across these columns, we vary both the regression specification and the estimation technique, without much effect. The remaining seven columns report analogues, for our preferred specification, when national representation shares at ECB management levels (instead of economic size) are used as weights. Our

\footnotetext{
${ }^{34}$ Extending the sample to also include more recent months would bias the Taylor rule estimate towards the output gap at the expense of the inflation rate (which becomes insignificant). This result is not too surprising, given that the ECB interest rates have been at record lows during times of financial crisis.

${ }^{35}$ More specifically, we compute the weighted average of the Consensus forecasts for the current year $(c)$ and the following year $(f)$. Expected inflation for country $i$ in year $t$, month $m$ is then given by $\pi_{i, t, m}^{e}=$ $\frac{13-m}{12} \pi_{i, t, m}^{c}+\frac{m-1}{12} \pi_{i, t, m}^{f}$, where $\pi_{i, t, m}^{c}$ and $\pi_{i, t, m}^{f}$ denote Consensus forecasts for country $i$ in year $t$, month $m$ for the rate of inflation (in percent) in the current and following year, respectively. An analogous procedure is used to compute expected output growth, where $\left[\frac{13-m}{12} \Delta \ln y_{i, t, m}^{c}+\frac{m-1}{12} \Delta \ln y_{i, t, m}^{f}\right] \times 100$, with $\Delta \ln y_{i, t, m}^{c}$ and $\Delta \ln y_{i, t, m}^{f}$ denoting Consensus forecasts for GDP growth (in percent) in the current and the following year, respectively; see also Gorter, Jacobs and de Haan (2008).

${ }^{36}$ All shares are defined with respect to the current size of euro area at time $t$ (that is, the shares always sum to one). Cyprus, Malta, and Luxembourg are dropped from our sample, because survey data from Consensus Economics is not available.

${ }^{37}$ Results turn out to be virtually identical when a country's capital subscription key in the ECB is used as weight; the results are not reported for the sake of brevity.
} 
measure of interest is the goodness of fit of the Taylor rule specification; we use the $R^{2}$, which corresponds to the squared correlation between the predicted values from the empirical model and the actual main refinancing rate.

The first column reports parameter estimates for the full model with no restrictions. As shown, the AR parameter $\delta$ is insignificant in our sample, which may be explained by the smooth time series properties of the main refinancing rate. In the next (and the following) column(s), therefore, we tabulate results for a specification when $\delta=0$. For this modification, the parameter estimates slightly decrease in magnitude, but the overall results remain essentially unchanged. Most notably, the point estimates of the parameters for expected inflation and the expected change in the output gap turn out to be virtually identical. The estimates imply that an increase in expected inflation (the expected change in the output gap) by 1 percentage point induces an increase in the ECB's main refinancing rate by 1.9 percent (that is, the expected real interest rate increases after an upsurge in inflation expectations). ${ }^{38}$ Also, interest rates display a high degree of persistence; the point estimate of $\rho$ indicates that about 10 percent of the difference between the actual rate and the target rate is closed each month. Finally, in light of the fact that the model is specified in first differences, the empirical fit of the regression is satisfactory, with an $R^{2}$ of 0.231 . For comparison, the implied squared correlation between the actual and predicted values of the level of the interest rate amounts to 0.857 .

Next, to address potential endogeneity concerns, we re-estimate the model by two stages least squares (2SLS), using the first and second time lag of the explanatory variables as instruments. For this estimation technique, the point estimates of the response parameters are virtually unchanged; moreover, a Hausman-type test cannot reject the null hypothesis that the least squares estimates and the 2SLS estimates are identical. Overall, we consider the (restricted) model in the second column of Table 6 as our preferred specification of the Taylor rule.

In the following, we apply this specification to estimate Taylor rules based on alternative weighting schemes for national data to compute euro area aggregrates of the inflation gap and the output gap. As argued above, if monetary policy is directed more strongly towards the

\footnotetext{
${ }^{38}$ The finding of symmetric weighting of inflation and economic growth in the ECB's monetary policy is a remarkable result, although not new to the literature. Sturm and Wollmershäuser (2008, p. 13) conclude that "the ECB takes movements in real variables at least as serious as movements in inflation".
} 
macroeconomic conditions in countries that are well represented in the ECB management, we would expect that Taylor rule specifications that use national representation as weights to aggregate national data provide a superior empirical fit than our default specification based on economic weights. Our benchmark value for the $R^{2}$ (correlation) is 0.231 (0.481).

We begin, mainly for completeness, with the results for national representation in the Governing Council and its two subgroups, the Executive Board and the group of the Governors of national central banks (with each Governor having a single vote in the Council). Reassuringly, given that Council members are expected to make decisions exclusively based on information for the euro area aggregate, national representation in the Council has no measurable effect on the appropriateness of ECB monetary policy for individual countries as measured by the empirical fit of the Taylor rule; the $R^{2}$ decreases from 0.23 to about 0.20 .

$<$ Table 6 here $>$

We then turn to the two top management layers of the ECB, directorates/directorates general and divisions. ${ }^{39}$ As shown in column 7 , the point estimates of the coefficients slightly differ from the regression based on economic weights; the estimated $\beta$ coefficient on the inflation gap even becomes insignificant, which casts some doubt on this specification. Moreover, the $R^{2}$ falls notably to 0.184 when national representation at the directorates level of the ECB is used to aggregate national macroeconomic data. While the findings for divisions display a much better empirical fit, the $R^{2}$ of 0.229 is basically identical to the baseline model with economic weights.

Finally, we use aggregate measures of national representation in the ECB management (which also cover sections after their establishment in 2004). When a country's share in the total number of managers is used as weight, the empirical fit of the regression is slightly better than in the baseline version of the Taylor rule; the $R^{2}$ increases to 0.235 . For national representation shares in the ECB's core business areas, the results turn out to become even more remarkable; the $R^{2}$ jumps to 0.248 , an increase by 8 percent in relative terms compared with the specification in column 2. Without taking the precise estimates too literally, the

\footnotetext{
${ }^{39}$ We do not consider national shares at the level of sections, which would reduce the time period with available data for the time series model to merely four and a half years.
} 
results clearly indicate that national representation in ECB's key units for business operations have an effect on the formulation of ECB monetary policy. ${ }^{40}$

In extensive sensitivity analyses, we examine the robustness of our results. Specifically, we experiment with three perturbations of our underlying empirical model. First, we examine the subsample stability of our estimation results. In particular, we rerun the regressions for shorter sample periods, starting in 2000:1, 2001:1, 2002:1, and 2003:1 respectively (all samples end in 2008:6). Second, we replace the ECB's main refinancing rate as dependent variable affects our results, using the 3-months Euribor and the Eonia as alternative measures. Finally, we extend our list of weighting schemes to combine national economic data. In addition to the (eight) weights reported in Table 6, we examine national representation among heads and deputies of the ECB (separately for directorates, divisions and total) as well as national representation among heads of core business areas (again separately for directorates and divisions). In total, we explore 195 ( $=5$ periods $\times 3$ policy measures $\times 13$ weighting schemes) different regression specifications of the Taylor rule.

\section{$<$ Table 7 here $>$}

Table 7 summarizes the results. Instead of reporting the full set of estimated coefficients, we focus on the statistical parameter of interest, the empirical fit of the regressions. Specifically, we tabulate the average (minimum, maximum) rank of the $R^{2}$ of the baseline specification of the Taylor rule when national data are combined in proportion to the economic weight of the country along with complementary findings for two other selected specifications. As shown in the left panel of the table, it seems remarkable that the specification of the Taylor rule for economically-weighted data never performs best; its average rank is 7 (out of 13 different weighting schemes). Similarly, we replicate our earlier finding that Taylor rules tend to display, not surprisingly, a particularly poor empirical fit for weighting schemes based on national representation in management areas with a strong egalitarian composition, such as

\footnotetext{
${ }^{40}$ We also perform a more rigorous statistical assessment of the (non-nested) models, using the Davidson and McKinnon J-test. This exercise yields generally inconclusive results. Adding the fitted interest rate from the Taylor rule for economically-weighted data (column 2) to the specification for representation weights (column 10) yields a $p$-value of 0.83 ; and while the $p$-value of adding the fitted value from column 10 to column 2 is lower (0.60), it is still far away from conventional significance levels. Hence, the test does not allow us to reject one model against the other.
} 
the Governing Council, the Executive Board, the Governors of national central banks ('equal weighting'), and the heads of directorates . On average, a Taylor rule specification for euro area aggregates into which national data enter fully symmetrically ranks ninth (out of 13), although with a somewhat wider distribution. In contrast, Taylor rules turn out to describe the ECB's interest rate setting behavior particularly well for aggregates based on national representation among the heads of divisions and the ECB management in general, especially if the analysis is additionally restricted on representation in the core business areas. Overall, national representation shares in the ECB's core business areas provide the best empirical fit of the Taylor rule in almost every specification. The three columns on the extreme right of Table 7 report the relative increase in the $R^{2}$ relative to the baseline Taylor rule with economic weights. Depending on the specification, the differences range from 6 to 22 percent (in relative terms), indicating that the estimates reported in Table 6 (with a difference of about 8 percent) are rather at the lower bound.

To further assess the effects of differences in weighting schemes, we examine hypothetical interest rate paths. Specifically, we ask: Would monetary policy have been fundamentally different if the ECB had followed the Taylor rule with economically-weighted data? For this purpose, we replicate the interest rate setting behavior of the ECB using the best-fitting Taylor rule (based on the number of heads in the core business areas) and simulate the interest rate path when the representation-weighted euro area aggregates are replaced with their sizeweighted values. While the correlation between both weighting schemes is strong, with about 0.90, the implied differences in monetary policy also depend on the degree of business cycle synchronization across countries. ${ }^{41}$

$<$ Figure 1 here $>$

Figure 1 illustrates the results of this simulation exercise, comparing actual and predicted interest rates (using dynamic forecasting, carrying forward the discrepancy) over the sample period. The difference turns out to be of sizable economic importance. If the ECB's monetary policy had been appropriately applied on national economic data in proportion to the economic size of the euro area member countries, the main refinancing rate would have been lower by, on average, about 0.31 percentage points. For subperiods, the deviation of the hypothetical interest rate even increases to about 0.61 percentage points. In sum, the results

\footnotetext{
${ }^{41}$ For the extreme case of perfectly correlated business cycles, the weighting of national data would be irrelevant.
} 
clearly indicate that even moderate differences in weighting schemes can have sizeable consequences for the outcome.

Overall, we find that Taylor rules taking into account national presence in the key policymaking positions of the organization tend to outperform specifications purely based on economic weights. National representation in the ECB may well exert a measurable influence on the conduct of monetary policy.

\section{Conclusions}

Supranational institutions face an important trade-off when hiring personnel. As in most organizations, hiring decisions are mainly based on a candidate's professional qualifications. In addition, however, supranational institutions often aim for broad national representation, for various reasons. Potential benefits include greater diversity of personal backgrounds and access to local knowledge which may help implement policies (potentially leading to broader acceptance). At the same time, however, cultural issues may also become a hindrance to organizational success. Possible costs include forgoing talent for geographic variety, network effects and a national bias in decision-making.

Looking at the European Central Bank, we show that nationality is indeed relevant for both hiring and decision-making. We find a disproportionately narrow spread of national representation in the top management of the ECB. Further, there is evidence for the existence of national networks between adjacent management layers. Finally, monetary policy decisions seem to be linked to national representation in the core business areas of the ECB. 


\section{References}

Baldwin, Richard and Charles Wyplosz. 2009. The Economics of European Integration. Third Edition. Berkshire: McGraw-Hill.

Belke, Ansgar and Barbara von Schnurbein. 2012. "European Monetary Policy and the ECB Rotation Model," Public Choice. 151 (April): 289-323.

Berger, Helge and Jakob De Haan. 2002. "Are Small Countries Too Powerful Within the ECB?" Atlantic Economic Journal. 30 (September): 263-280.

Berger, Helge and Till Mueller. 2007. "How Should Large and Small Countries Be Represented in a Currency Union," Public Choice. 132 (September): 471-484.

Berger, Helge and Volker Nitsch. 2011. "Too Many Cooks? Committees in Monetary Policy," Southern Economic Journal. 78 (October): 452-475.

Berger, Helge, Volker Nitsch, and Tonny Lybek. 2008. "Central Bank Boards around the World: Why Does Membership Size Differ?" European Journal of Political Economy. 24 (December): 817-832.

Bertrand, Marianne and Antoinette Schoar. 2003. "Managing With Style: The Effect of Managers on Firm Policies," Quarterly Journal of Economics. 68 (November): 1169-1208.

Besley, Timothy, Jose G. Montalvo and Marta Reynal-Querol. 2011. "Do Educated Leaders Matter?" Economic Journal. 121 (August): F205-F227.

Chappell Jr., Henry W., Rob Roy McGregor, and Todd A Vermilyea. 2008. "Regional Economic Conditions and Monetary Policy," European Journal of Political Economy. 24 (June): 283-293.

Dreher, Axel, Michael J. Lamla, Sarah M. Lein, and Frank Somogyi. 2009. "The Impact of Political Leaders' Profession and Education on Reforms," Journal of Comparative Economics. 37 (March): 169-183.

Egeberg, Morten. 1996. "Organization and Nationality in the European Commission Services," Public Administration. 74 (Winter): 721-735.

English, William B., William R. Nelson, and Brian P. Sack. 2003. "Interpreting the Significance of the Lagged Interest Rate in Estimated Monetary Policy Rules," Contributions to Macroeconomics. 3 (1): Article 5.

Gerlach-Kristen, Petra. 2006. "Monetary Policy Committees and Interest Rate Setting," European Economic Review. 50: 487-507.

Gildea, John A. 1992. "The Regional Representation of Federal Reserve Bank Presidents," Journal of Money, Credit and Banking. 24: 215-225. 
Göhlmann, Silja and Roland Vaubel. 2007. "The Educational and Occupational Background of Central Bankers and its Effect on Inflation: An Empirical Analysis," European Economic Review. 51 (May): 925-941.

Goodfriend, Marvin. 1999. "The Role of a Regional Bank in a System of Central Banks," Carnegie-Rochester Conference Series on Public Policy. 51 (December): 51-71.

Gorter, Janko, Jan Jacobs, and Jakob de Haan. 2008. "Taylor Rules for the ECB using Expectations Data," Scandinavian Journal of Economics. 110 (3): 473-488.

Hayo, Bernd and Pierre-Guillaume Méon. 2011. "Behind Closed Doors: Revealing the ECB's Decision Rule," MAGKS Discussion Paper No. 35-2011.

Heinemann, Friedrich and Felix P. Huefner. 2004. "Is the View from the Eurotower purely European? National Divergence and ECB Interest Rate Policy," Scottish Journal of Political Economy. 51 (September): 544-558.

Meade, Ellen and Nathan Sheets. 2005. "Regional Influences on FOMC Voting Patterns," Journal of Money, Credit and Banking. 37 (4): 661-678.

Michelmann, Hans J. 1978. "Multinational Staffing and Organizational Functioning in the Commission of the European Communities," International Organization. 32 (Spring): 477496.

Pfeffer, Jeffrey. 1985. "Organizational Demography: Implications for Management," California Management Review. 28 (Fall): 67-81.

Scheller, Hanspeter K. 2004. The European Central Bank: History, Role and Functions. Frankfurt am Main: European Central Bank.

Sturm, Jan-Egbert and Jakob de Haan. 2011. "Does Central Bank Communication Really Lead to Better Forecasts of Policy Decisions? New Evidence based on a Taylor Rule Model for the ECB," Review of World Economics. 147 (April): 41-58.

Sturm, Jan-Egbert and Timo Wollmershäuser. 2008. "The Stress of Having A Single Monetary Policy in Europe," CESifo Working Paper 2251.

Walsh, Carl E. 2003. "Implications of a Changing Economic Structure for the Strategy of Monetary Policy," Monetary Policy and Uncertainty: Adapting to a Changing Economy. Jackson Hole Symposium, Federal Reserve Bank of Kansas City. 
Table 1. The ECB: A Growing Institution

\begin{tabular}{|c|c|c|c|c|c|c|c|c|c|c|c|c|}
\hline & 1999 & 2000 & 2001 & 2002 & 2003 & 2004 & 2005 & 2006 & 2007 & 2008 & 2009 & 2010 \\
\hline Directorates & 18 & 20 & 20 & 21 & 21 & 21 & 20 & 20 & 20 & 20 & 20 & 19 \\
\hline Divisions & 34 & 49 & 51 & 52 & 53 & 51 & 52 & 52 & 52 & 52 & 54 & 55 \\
\hline Sections & - & - & - & - & - & 33 & 32 & 36 & 37 & 41 & 49 & 49 \\
\hline \multicolumn{13}{|l|}{ Additional information: } \\
\hline National Central Banks ${ }^{1}$ & 11 & 11 & 12 & 12 & 12 & 12 & 12 & 12 & 13 & 15 & 16 & 16 \\
\hline Executive Board & 6 & 6 & 6 & 6 & 6 & 6 & 6 & 6 & 6 & 6 & 6 & 6 \\
\hline ECB Staff $^{2}$ & 534 & 732 & 941 & 1,043 & 1,109 & 1,217 & 1,314 & 1,360 & $1,367^{3}$ & $1,478^{3}$ & $1,536^{3}$ & $1,563^{3}$ \\
\hline
\end{tabular}

Notes: The table lists the number of managers at different ECB management levels (no deputies). The data refer to the beginning of the year.

${ }^{1}$ Governors of national central banks of euro area member countries who are automatically member of the ECB Governing Council

${ }^{2}$ End of previous year. ${ }^{3}$ Full-time equivalent positions

Sources: Own compilations; various issues of the ECB's annual report. 
Table 2. Who Gets Appointed? Benchmark Results

\begin{tabular}{llllll}
\hline Heads & Directorates & Divisions & Sections & Total & Weighted \\
\hline Equal share $\left(S^{E}\right)$ & $0.214^{* * *}$ & 0.037 & -0.043 & 0.084 & $0.112^{* *}$ \\
& $(0.072)$ & $(0.055)$ & $(0.097)$ & $(0.053)$ & $(0.053)$ \\
Capital share $\left(S^{P}\right)$ & $0.786^{* * *}$ & $0.963^{* * *}$ & $1.036^{* * *}$ & $0.915^{* * *}$ & $0.888^{* * *}$ \\
& $(0.052)$ & $(0.068)$ & $(0.142)$ & $(0.063)$ & $(0.054)$ \\
$\mathrm{R}^{2}$ & 0.528 & 0.762 & 0.589 & 0.761 & 0.752 \\
SEE & 0.047 & 0.034 & 0.048 & 0.032 & 0.032 \\
Obs & 248 & 248 & 173 & 248 & 248
\end{tabular}

Heads and deputies

\begin{tabular}{llllll}
\hline Equal share $\left(S^{E}\right)$ & $\begin{array}{l}0.195^{* * *} \\
(0.068)\end{array}$ & $\begin{array}{l}0.037 \\
(0.050)\end{array}$ & $\begin{array}{l}-0.043 \\
(0.097)\end{array}$ & $\begin{array}{l}0.087^{*} \\
(0.051)\end{array}$ & $\begin{array}{l}0.113^{* *} \\
(0.051)\end{array}$ \\
Capital share $\left(S^{P}\right)$ & $\begin{array}{l}0.805^{* * *} \\
(0.055)\end{array}$ & $\begin{array}{l}0.963^{* * *} \\
(0.060)\end{array}$ & $\begin{array}{l}1.036^{* * *} \\
(0.142)\end{array}$ & $\begin{array}{l}0.912^{* * *} \\
(0.058)\end{array}$ & $\begin{array}{l}0.886^{* * *} \\
(0.051)\end{array}$ \\
$\mathrm{R}^{2}$ & 0.561 & 0.795 & 0.589 & 0.779 & 0.759 \\
SEE & 0.045 & 0.031 & 0.048 & 0.031 & 0.031 \\
Obs & 248 & 248 & 173 & 248 & 248
\end{tabular}

Heads, core business areas

\begin{tabular}{llllll}
\hline Equal share $\left(S^{E}\right)$ & $0.244^{* * *}$ & 0.093 & 0.044 & $0.147^{* *}$ & $0.164^{* * *}$ \\
& $(0.079)$ & $(0.059)$ & $(0.124)$ & $(0.062)$ & $(0.058)$ \\
Capital share $\left(S^{P}\right)$ & $0.756^{* * *}$ & $0.907^{* * *}$ & $0.956^{* * *}$ & $0.853^{* * *}$ & $0.836^{* * *}$ \\
& $(0.069)$ & $(0.065)$ & $(0.176)$ & $(0.069)$ & $(0.057)$ \\
$\mathrm{R}^{2}$ & 0.426 & 0.662 & 0.443 & 0.653 & 0.658 \\
SEE & 0.056 & 0.041 & 0.060 & 0.039 & 0.038 \\
Obs & 248 & 248 & 173 & 248 & 248 \\
\hline
\end{tabular}

Notes: Dependent variable is the share of representatives from country $i$ at time $t$ at the respective ECB management layer $\left(R_{i}^{\ell}\right)$. Robust standard errors in parentheses. ${ }^{* * *},{ }^{* *}$, and ${ }^{*}$ denote significant at the $1 \%, 5 \%$, and $10 \%$ level, respectively. 
Table 3. Who Gets Appointed? Adding Country Controls

\begin{tabular}{|c|c|c|c|c|c|c|c|}
\hline & Directorates & Divisions & Sections & Total & Weighted & Exec. Board & Gov. Council \\
\hline Equal share $\left(S^{E}\right)$ & $\begin{array}{l}0.379^{* * *} \\
(0.049)\end{array}$ & $\begin{array}{l}0.128^{* * *} \\
(0.039)\end{array}$ & $\begin{array}{l}0.001 \\
(0.078)\end{array}$ & $\begin{array}{l}0.178^{* * *} \\
(0.037)\end{array}$ & $\begin{array}{l}0.225^{* * *} \\
(0.034)\end{array}$ & $\begin{array}{l}0.530^{* * *} \\
(0.072)\end{array}$ & $\begin{array}{l}0.878^{* * *} \\
(0.027)\end{array}$ \\
\hline Capital share $\left(S^{P}\right)$ & 0.621 & 0.872 & 0.999 & 0.822 & 0.775 & 0.470 & 0.122 \\
\hline Restr. $\eta_{P}=1-\eta_{E}$ & - & - & - & - & - & - & - \\
\hline Euro area member & $\begin{array}{l}0.019^{* * *} \\
(0.006)\end{array}$ & $\begin{array}{l}-0.004 \\
(0.005)\end{array}$ & $\begin{array}{l}-0.013 \\
(0.010)\end{array}$ & $\begin{array}{l}0.000 \\
(0.006)\end{array}$ & $\begin{array}{l}0.005 \\
(0.005)\end{array}$ & $\begin{array}{l}0.046^{* * *} \\
(0.013)\end{array}$ & $\begin{array}{l}0.062^{* * *} \\
(0.005)\end{array}$ \\
\hline Length of membership & $\begin{array}{l}0.006^{* * *} \\
(0.001)\end{array}$ & $\begin{array}{l}0.003^{* * *} \\
(0.001)\end{array}$ & $\begin{array}{l}0.001 \\
(0.002)\end{array}$ & $\begin{array}{l}0.003^{* * *} \\
(0.001)\end{array}$ & $\begin{array}{l}0.004^{* * *} \\
(0.001)\end{array}$ & $\begin{array}{l}0.005^{* * *} \\
(0.002)\end{array}$ & $\begin{array}{l}0.002^{* * *} \\
(0.001)\end{array}$ \\
\hline Distance & $\begin{array}{l}-0.014^{* * *} \\
(0.002)\end{array}$ & $\begin{array}{l}-0.006^{* * *} \\
(0.001)\end{array}$ & $\begin{array}{l}-0.006^{* *} \\
(0.003)\end{array}$ & $\begin{array}{l}-0.007^{* * *} \\
(0.001)\end{array}$ & $\begin{array}{l}-0.009^{* * *} \\
(0.001)\end{array}$ & $\begin{array}{l}-0.003 \\
(0.004)\end{array}$ & $\begin{array}{l}-0.006^{* * *} \\
(0.001)\end{array}$ \\
\hline Border & $\begin{array}{l}0.020^{* * *} \\
(0.006)\end{array}$ & $\begin{array}{l}-0.014^{* * *} \\
(0.005)\end{array}$ & $\begin{array}{l}-0.052^{* * *} \\
(0.007)\end{array}$ & $\begin{array}{l}-0.015^{* * *} \\
(0.005)\end{array}$ & $\begin{array}{l}-0.005 \\
(0.004)\end{array}$ & $\begin{array}{l}-0.011 \\
(0.008)\end{array}$ & $\begin{array}{l}-0.007^{* *} \\
(0.003)\end{array}$ \\
\hline Staff NCB & $\begin{array}{l}0.079^{* * *} \\
(0.013)\end{array}$ & $\begin{array}{l}0.057^{* * *} \\
(0.010)\end{array}$ & $\begin{array}{l}0.055^{* * *} \\
(0.020)\end{array}$ & $\begin{array}{l}0.055^{* * *} \\
(0.009)\end{array}$ & $\begin{array}{l}0.061^{* * *} \\
(0.009)\end{array}$ & $\begin{array}{l}-0.008 \\
(0.023)\end{array}$ & $\begin{array}{l}0.006 \\
(0.008)\end{array}$ \\
\hline Education & $\begin{array}{l}0.078^{* * *} \\
(0.021)\end{array}$ & $\begin{array}{l}0.012 \\
(0.011)\end{array}$ & $\begin{array}{l}0.025 \\
(0.024)\end{array}$ & $\begin{array}{l}0.028^{* *} \\
(0.011)\end{array}$ & $\begin{array}{l}0.038^{* * *} \\
(0.012)\end{array}$ & $\begin{array}{l}-0.013 \\
(0.035)\end{array}$ & $\begin{array}{l}0.003 \\
(0.012)\end{array}$ \\
\hline German & $\begin{array}{l}-0.025^{* *} \\
(0.011)\end{array}$ & $\begin{array}{l}0.072^{* * *} \\
(0.011)\end{array}$ & $\begin{array}{l}0.117^{* * *} \\
(0.017)\end{array}$ & $\begin{array}{l}0.057^{* * *} \\
(0.011)\end{array}$ & $\begin{array}{l}0.039^{* * *} \\
(0.010)\end{array}$ & $\begin{array}{l}0.007 \\
(0.020)\end{array}$ & $\begin{array}{l}-0.006 \\
(0.007)\end{array}$ \\
\hline$R^{2}$ & 0.790 & 0.901 & 0.811 & 0.894 & 0.900 & 0.821 & 0.554 \\
\hline SEE & 0.032 & 0.024 & 0.035 & 0.023 & 0.022 & 0.020 & 0.053 \\
\hline Obs & 212 & 212 & 152 & 212 & 212 & 212 & 212 \\
\hline
\end{tabular}

Notes: Dependent variable is the share of representatives from country $i$ at time $t$ at the respective ECB management layer $\left(R_{i}^{\ell}\right)$. Robust standard errors in parentheses. $^{* * *},{ }^{* *}$, and ${ }^{*}$ denote significant at the $1 \%, 5 \%$, and $10 \%$ level, respectively. 
Table 4. Who Gets Appointed? Robustness Checks

\begin{tabular}{|c|c|c|c|c|c|}
\hline & $\begin{array}{l}\text { Confirmed } \\
\text { nationality only }\end{array}$ & $\begin{array}{l}\text { Heads } \\
\text { and deputies }\end{array}$ & $\begin{array}{l}\text { Core } \\
\text { business areas }\end{array}$ & $\begin{array}{l}\text { Core business areas, } \\
\text { heads and deputies }\end{array}$ & Germany dropped \\
\hline Equal share $\left(S^{E}\right)$ & $\begin{array}{l}0.193^{* * *} \\
(0.034)\end{array}$ & $\begin{array}{l}0.192^{* * *} \\
(0.035)\end{array}$ & $\begin{array}{l}0.240^{* * *} \\
(0.053)\end{array}$ & $\begin{array}{l}0.235^{* * *} \\
(0.050)\end{array}$ & $\begin{array}{l}0.333^{* * *} \\
(0.033)\end{array}$ \\
\hline Capital share $\left(S^{P}\right)\left(\eta_{P}=1-\eta_{E}\right)$ & 0.807 & 0.808 & 0.760 & 0.765 & 0.667 \\
\hline Euro area member & $\begin{array}{l}0.004 \\
(0.005)\end{array}$ & $\begin{array}{l}0.005 \\
(0.005)\end{array}$ & $\begin{array}{l}0.018^{* *} \\
(0.008)\end{array}$ & $\begin{array}{l}0.022^{* * *} \\
(0.008)\end{array}$ & $\begin{array}{l}0.009^{* *} \\
(0.004)\end{array}$ \\
\hline Length of membership & $\begin{array}{l}0.002^{* * *} \\
(0.001)\end{array}$ & $\begin{array}{l}0.003^{* * *} \\
(0.001)\end{array}$ & $\begin{array}{l}0.002 \\
(0.001)\end{array}$ & $\begin{array}{l}0.002^{*} \\
(0.001)\end{array}$ & $\begin{array}{l}0.001^{*} \\
(0.000)\end{array}$ \\
\hline Distance & $\begin{array}{l}-0.007^{* * *} \\
(0.001)\end{array}$ & $\begin{array}{l}-0.009^{* * *} \\
(0.001)\end{array}$ & $\begin{array}{l}-0.006^{* * *} \\
(0.002)\end{array}$ & $\begin{array}{l}-0.008^{* * *} \\
(0.002)\end{array}$ & $\begin{array}{l}-0.006^{* * *} \\
(0.001)\end{array}$ \\
\hline Border & $\begin{array}{l}-0.017^{* * *} \\
(0.005)\end{array}$ & $\begin{array}{l}-0.009^{* *} \\
(0.005)\end{array}$ & $\begin{array}{l}-0.021^{* * *} \\
(0.006)\end{array}$ & $\begin{array}{l}-0.011^{*} \\
(0.006)\end{array}$ & $\begin{array}{l}0.002 \\
(0.004)\end{array}$ \\
\hline Staff NCB & $\begin{array}{l}0.054^{* * *} \\
(0.010)\end{array}$ & $\begin{array}{l}0.061^{* * *} \\
(0.009)\end{array}$ & $\begin{array}{l}0.038^{* * *} \\
(0.013)\end{array}$ & $\begin{array}{l}0.055^{* * *} \\
(0.013)\end{array}$ & $\begin{array}{l}0.025^{* * *} \\
(0.006)\end{array}$ \\
\hline Education & $\begin{array}{l}0.021^{*} \\
(0.011)\end{array}$ & $\begin{array}{l}0.037^{* * *} \\
(0.011)\end{array}$ & $\begin{array}{l}0.018 \\
(0.014)\end{array}$ & $\begin{array}{l}0.034^{* *} \\
(0.013)\end{array}$ & $\begin{array}{l}0.025^{* * *} \\
(0.008)\end{array}$ \\
\hline German & $\begin{array}{l}0.067^{* * *} \\
(0.011)\end{array}$ & $\begin{array}{l}0.046^{* * *} \\
(0.010)\end{array}$ & $\begin{array}{l}0.032^{* *} \\
(0.015)\end{array}$ & $\begin{array}{l}0.020 \\
(0.014)\end{array}$ & $\begin{array}{l}0.012 \\
(0.007)\end{array}$ \\
\hline$R^{2}$ & 0.902 & 0.900 & 0.787 & 0.803 & 0.873 \\
\hline SEE & 0.022 & 0.022 & 0.032 & 0.031 & 0.015 \\
\hline Obs & 212 & 212 & 212 & 212 & 200 \\
\hline
\end{tabular}

Notes: Dependent variable is the share of representatives from country $i$ at time $t$ at the respective ECB management layer $\left(R_{i}^{\ell}\right)$. Robust standard errors in parentheses. $^{* * *},{ }^{* *}$, and ${ }^{*}$ denote significant at the $1 \%, 5 \%$, and $10 \%$ level, respectively. 
Table 5. Does Presence in Top Management Matter?

\begin{tabular}{|c|c|c|c|c|c|c|c|}
\hline & Directorates & Divisions & Divisions & Sections & Sections & Sections & Sections \\
\hline President & $\begin{array}{l}0.013^{* * *} \\
(0.003)\end{array}$ & $\begin{array}{l}0.014^{* * *} \\
(0.003)\end{array}$ & $\begin{array}{l}0.013^{* * *} \\
(0.003)\end{array}$ & $\begin{array}{l}0.024^{* * *} \\
(0.005)\end{array}$ & $\begin{array}{l}0.027^{* * *} \\
(0.005)\end{array}$ & $\begin{array}{l}0.022^{* * *} \\
(0.005)\end{array}$ & $\begin{array}{l}0.025^{* * *} \\
(0.005)\end{array}$ \\
\hline Vice President & $\begin{array}{l}0.024 \\
(0.018)\end{array}$ & $\begin{array}{l}-0.026^{* * *} \\
(0.008)\end{array}$ & $\begin{array}{l}-0.029^{* * *} \\
(0.008)\end{array}$ & $\begin{array}{l}-0.067^{* * *} \\
(0.017)\end{array}$ & $\begin{array}{l}-0.062^{* * *} \\
(0.018)\end{array}$ & $\begin{array}{l}-0.062^{* * *} \\
(0.020)\end{array}$ & $\begin{array}{l}-0.048^{* *} \\
(0.023)\end{array}$ \\
\hline $\begin{array}{l}\text { Other Member } \\
\text { Executive Board }\end{array}$ & $\begin{array}{l}-0.005 \\
(0.005)\end{array}$ & $\begin{array}{l}-0.008 \\
(0.005)\end{array}$ & $\begin{array}{l}-0.007 \\
(0.005)\end{array}$ & $\begin{array}{l}-0.017^{* *} \\
(0.008)\end{array}$ & $\begin{array}{l}-0.019^{* *} \\
(0.008)\end{array}$ & $\begin{array}{l}-0.013^{*} \\
(0.006)\end{array}$ & $\begin{array}{l}-0.010^{*} \\
(0.006)\end{array}$ \\
\hline Directorate & & & $\begin{array}{l}0.084 \\
(0.071)\end{array}$ & & $\begin{array}{l}-0.221^{* *} \\
(0.108)\end{array}$ & & $\begin{array}{l}-0.404^{* * *} \\
(0.146)\end{array}$ \\
\hline Division & & & & & & $\begin{array}{l}0.219 \\
(0.250)\end{array}$ & $\begin{array}{l}0.531^{*} \\
(0.294)\end{array}$ \\
\hline $\mathrm{R}^{2}$ & 0.795 & 0.898 & 0.900 & 0.815 & 0.821 & 0.834 & 0.795 \\
\hline SEE & 0.032 & 0.025 & 0.025 & 0.035 & 0.035 & 0.034 & 0.032 \\
\hline Obs & 212 & 212 & 212 & 152 & 152 & 152 & 212 \\
\hline
\end{tabular}

Notes: Dependent variable is the share of representatives from country $i$ at time $t$ at the respective ECB management layer $\left(R_{i}^{\ell}\right)$. Other regressors, analogous to the specification in Table 3, included, but not reported. Robust standard errors in parentheses. ${ }^{* * *}$, ${ }^{* *}$, and ${ }^{*}$ denote significant at the $1 \%$, $5 \%$, and $10 \%$ level, respectively. 
Table 6. Taylor Rule Estimates for the Euro Area Using Alternative Weighting Schemes

\begin{tabular}{|c|c|c|c|c|c|c|c|c|c|c|}
\hline & \multicolumn{3}{|c|}{ Economic weight } & \multicolumn{7}{|c|}{ Representation weight } \\
\hline & Real GDP & Real GDP & Real GDP & $\begin{array}{l}\text { Govern'g } \\
\text { Council }\end{array}$ & $\begin{array}{c}\text { Executive } \\
\text { Board }\end{array}$ & $\begin{array}{c}\text { NCB } \\
\text { Governors }\end{array}$ & Direct's & Divisions & Total & $\begin{array}{l}\text { Total, } \\
\text { core }\end{array}$ \\
\hline \multirow[t]{2}{*}{ Constant } & $3.623^{* *}$ & $3.615^{* *}$ & $3.629^{* *}$ & $2.390^{* *}$ & $2.639^{* *}$ & $2.317^{* *}$ & $3.573^{* *}$ & $3.397^{* *}$ & $3.351^{* *}$ & $3.129^{* *}$ \\
\hline & $(0.199)$ & $(0.195)$ & $(0.22)$ & $(0.149)$ & (0.198) & $(0.137)$ & $(0.248)$ & $(0.155)$ & $(0.149)$ & $(0.121)$ \\
\hline \multirow[t]{2}{*}{ Inflation gap $(\beta)$} & $1.977^{* *}$ & $1.881^{* *}$ & $1.933^{* *}$ & $1.620^{* *}$ & $1.604^{* *}$ & $1.589^{* *}$ & 1.264 & $1.949^{* *}$ & $1.845^{* *}$ & $1.707^{* *}$ \\
\hline & $(0.508)$ & $(0.476)$ & $(0.586)$ & $(0.463)$ & $(0.636)$ & $(0.435)$ & $(0.858)$ & $(0.441)$ & $(0.447)$ & $(0.391)$ \\
\hline \multirow[t]{2}{*}{ Output gap $(\gamma)$} & $1.923^{* *}$ & $1.891^{* *}$ & $1.947^{* *}$ & $1.802^{* *}$ & $2.405^{* *}$ & $1.552^{* *}$ & $1.705^{* *}$ & $1.414^{* *}$ & $1.496^{* *}$ & $1.557^{* *}$ \\
\hline & $(0.314)$ & $(0.312)$ & $(0.371)$ & $(0.300)$ & $(0.510)$ & $(0.256)$ & $(0.441)$ & $(0.237)$ & $(0.252)$ & $(0.239)$ \\
\hline \multirow[t]{2}{*}{ Speed of adjustment $(\rho)$} & $0.900^{* *}$ & $0.897^{* *}$ & $0.907^{* *}$ & $0.889^{* *}$ & $0.921^{* *}$ & $0.876^{* *}$ & $0.908^{* *}$ & $0.883^{* *}$ & $0.886^{* *}$ & $0.882^{* *}$ \\
\hline & $(0.029)$ & $(0.030)$ & $(0.031)$ & $(0.034)$ & $(0.025)$ & $(0.042)$ & $(0.036)$ & $(0.032)$ & $(0.032)$ & $(0.031)$ \\
\hline \multirow[t]{2}{*}{ AR parameter $(\delta)$} & -0.111 & & & & & & & & & \\
\hline & $(0.056)$ & & & & & & & & & \\
\hline Estimation method & OLS & OLS & 2SLS & OLS & OLS & OLS & OLS & OLS & OLS & OLS \\
\hline $\mathrm{R}^{2}$ & 0.244 & 0.231 & 0.211 & 0.208 & 0.199 & 0.201 & 0.184 & 0.229 & 0.235 & 0.248 \\
\hline Obs & 112 & 113 & 112 & 113 & 113 & 113 & 113 & 113 & 113 & 113 \\
\hline
\end{tabular}

Notes: Dependent variable is the (change in the) main refinancing rate. Heteroskedasticity and autocorrelation robust standard errors in parentheses. ${ }^{* *}$ denotes significant at the $1 \%$ level. 
Table 7. Summary Results of Taylor Rule Estimates for the Euro Area Using Alternative Weighting Schemes and Specifications

\begin{tabular}{|c|c|c|c|c|c|c|c|c|c|}
\hline & \multicolumn{3}{|c|}{ Economic weight } & \multicolumn{3}{|c|}{ Equal weight } & \multirow{2}{*}{\multicolumn{3}{|c|}{$\frac{\text { Representation weight (Total, core) }}{\Delta R^{2} \text { (relative, in \%) }}$}} \\
\hline & \multicolumn{3}{|c|}{$\mathrm{rk} R^{2}$} & \multicolumn{3}{|c|}{ rk of $R^{2}$} & & & \\
\hline & Average & Min. & Max. & Average & Min. & Max. & Average & Min. & Max. \\
\hline 3-month Euribor & 7 & 5 & 8 & 9 & 6 & 12 & 10.42 & 7.28 & 14.40 \\
\hline Eonia & 7 & 3 & 9 & 5 & 4 & 12 & 11.34 & 6.27 & 19.81 \\
\hline
\end{tabular}

Notes: The table reports the rank of the $R^{2}$ of the Taylor rule out of 13 specifications. $\Delta R^{2}$ refers to the relative difference of the $R^{2}$ to the Taylor rule specification using economic weights. 
Figure 1. Main Refinancing Rate and Counterfactual Based on Economic Weights (\%)

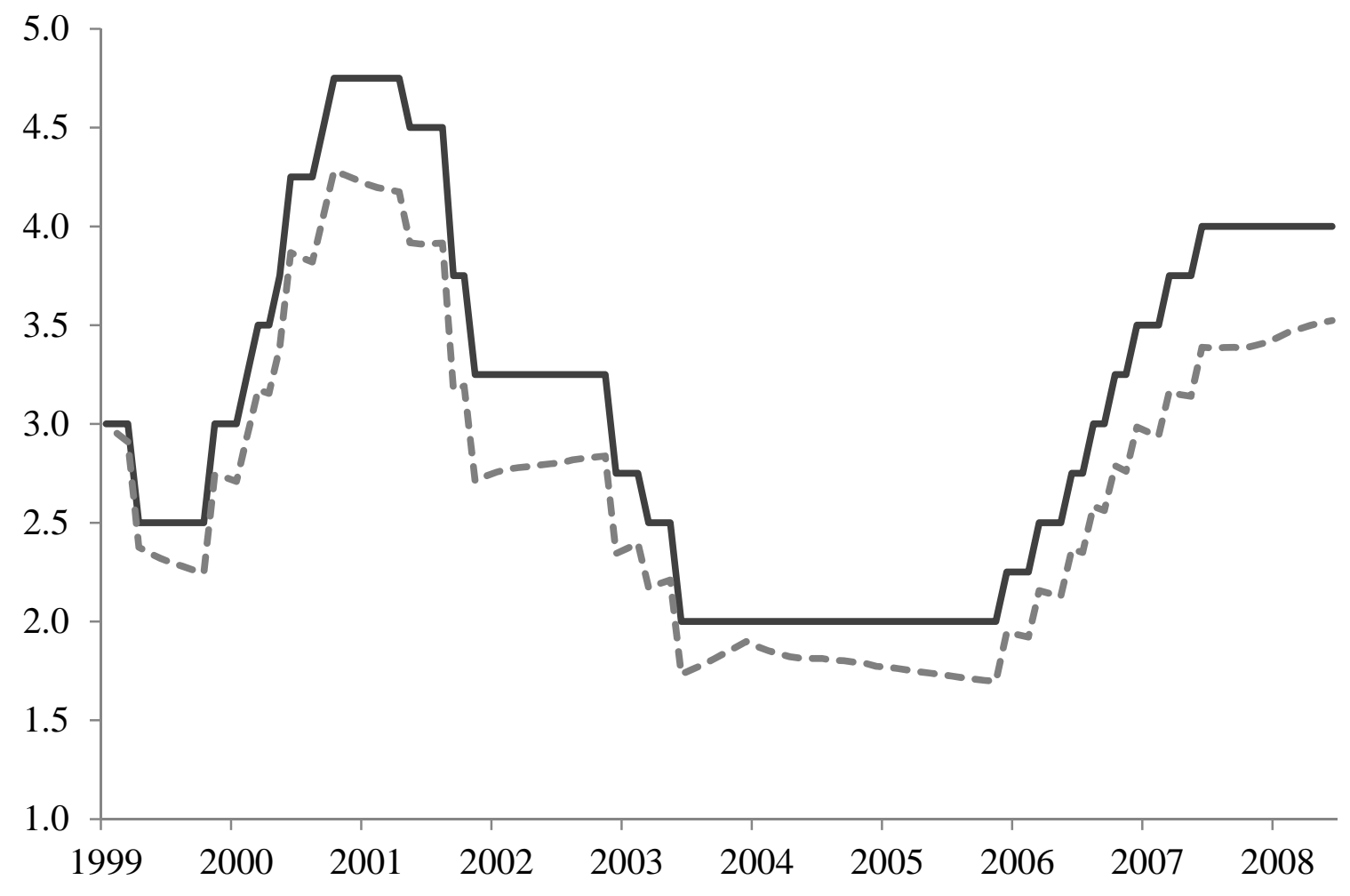

Notes: Main refinancing rate (line); predicted rate (dotted). 
Appendix: Data Description and Sources

\begin{tabular}{|c|c|c|c|c|c|c|c|}
\hline Variable & Description & Source & Obs. & Mean & SD & Min. & Max. \\
\hline Dir., Dir. General & Country share of ECB directors & Own computation & 248 & 0.048 & 0.068 & 0 & 0.250 \\
\hline Divisions & Country share of ECB division heads & Own computation & 248 & 0.048 & 0.069 & 0 & 0.346 \\
\hline Sections & Country share of ECB section heads & Own computation & 173 & 0.048 & 0.075 & 0 & 0.408 \\
\hline Total & $\begin{array}{l}\text { Country share of ECB managers (total number } \\
\text { of heads of directorate, division and section) }\end{array}$ & Own computation & 248 & 0.048 & 0.065 & 0 & 0.350 \\
\hline Weighted & $\begin{array}{l}\text { Country share of ECB managers (weighted } \\
\text { number of heads of directorate [weight of } 1] \text {, } \\
\text { division }[0.5] \text { and section }[0.25] \text { ) }\end{array}$ & Own computation & 248 & 0.048 & 0.064 & 0 & 0.315 \\
\hline Executive Board & Country share of Executive Board members & Own computation & 248 & 0.048 & 0.076 & 0 & 0.167 \\
\hline Governing Council & Country share of Governing Council members & Own computation & 248 & 0.048 & 0.044 & 0 & 0.118 \\
\hline Equal Share & 1/Number of EU member countries & Own computation & 248 & 0.048 & 0.014 & 0.037 & 0.067 \\
\hline Capital Share & ECB Capital Subscription Share & ECB & 248 & 0.048 & 0.062 & 0.001 & 0.245 \\
\hline Euro Area Member & $\begin{array}{l}\text { Dummy }=1 \text { if country is member of the euro } \\
\text { area }\end{array}$ & Own computation & 248 & 0.621 & 0.486 & 0 & 1 \\
\hline Distance & $\begin{array}{l}\text { Distance of national capital from Frankfurt in } \\
\text { km (Germany: } 150 \mathrm{~km})\end{array}$ & Own computation & 248 & 970.5 & 580.7 & 150 & 2596 \\
\hline Border & $\begin{array}{l}\text { Dummy = } 1 \text { if country has common border with } \\
\text { Germany }\end{array}$ & Own computation & 248 & 0.339 & 0.474 & 0 & 1 \\
\hline German & Dummy = 1 if German is official language & Own computation & 248 & 0.097 & 0.296 & 0 & 1 \\
\hline English & Dummy = 1 if English is official language & Own computation & 248 & 0.145 & 0.353 & 0 & 1 \\
\hline Staff NCB & Log staff size of national central bank & Central Bank Directory & 248 & 2792.7 & 4001.9 & 140 & 16077 \\
\hline $\begin{array}{l}\text { Main Refinancing } \\
\text { Rate }\end{array}$ & Main refinancing rate & ECB & 114 & 3.066 & 0.896 & 2 & 4.75 \\
\hline Inflation Gap & $\begin{array}{l}\text { Deviation of professional forecast of CPI } \\
\text { inflation from inflation target of } 2 \%\end{array}$ & Consensus Economics & 114 & -0.104 & 0.279 & -0.851 & 0.74 \\
\hline Output Gap & $\begin{array}{l}\text { Deviation of professional forecast of GDP } \\
\text { growth from potential growth of } 2.25 \%\end{array}$ & Consensus Economics & 114 & -0.15 & 0.534 & -0.984 & 1.086 \\
\hline Education & $\begin{array}{l}\text { Share of population with upper and tertiary } \\
\text { education }\end{array}$ & Eurostat & 248 & 0.655 & 0.147 & 0.211 & 0.856 \\
\hline German speaking & $\begin{array}{l}\text { Share of population speaking German (self- } \\
\text { reported language knowledge) }\end{array}$ & Eurostat & 248 & 0.268 & 0.292 & 0.024 & 99.4 \\
\hline
\end{tabular}

